\title{
KOREOGRAFI SANCTAE FAMILIAE KARYA MATHEUS WASI BANTOLO
}

\author{
Trisila Wahyu Kinasih \\ Institut Seni Indonesia (ISI) Surakarta \\ Jalan Ki Hadjar Dewantara No. 19 Kentingan, Jebres, Surakarta 57126 \\ Matheus Wasi Bantolo \\ Institut Seni Indonesia (ISI) Surakarta
}

\begin{abstract}
Sanctae Familliae is a work created by Matheus Wasi Bantolo to commemorate the Christmas feast day in 2014. The problem in this study was (1) how the choreography Sanctae Familiae and (2) How the creativity of Matheus Wasi Bantolo in the work. In this study using qualitative research methods, with the approach of choreography. To get an answer from the problem about the form of the work of Sanctae Familiae using the concept of Sumandiyo Hadi on the elements of dance consisting of A.) Motion Dance, B.) Makeup and clothing, C.) Dance accompaniment, D.) Lighting, E.) Number of dancers and genders, F.) Theme, G.) Dance room, H.) Dance title, I.) mode or way of presentation, J.) Type of dance. To know the creativity of Matheus Wasi Bantolo uses the concept of Alma. M Hawkins. Creativity is a special ability to create something new, to achieve it is done three stages of creativity, namely exploration, improvisation, and composition. The essence of the work is the fight between angels representing goodness and demons that symbolize ugliness, and is similar to black and white. All men are the same in the eyes of God, which means no difference. Because love does not know goodness or ugliness, because God is love. The results of this study suggest that the choreography of Sanctae Familiae was formed from the life experiences of Matheus Wasi Bantolo, and because of his desire to give an outside form of his response and his unique imagination. Sanctae Familiae is realized through motion, music, drama that is packaged in the form of opera, is the result of creativity, the sensitivity of the environment, the experience of life and its imagination Matheus Wasi Bantolo. So he managed to present Sanctae Familiae choreography with totality.
\end{abstract}

Keywords: Sanctae Familiae, choreography, creativity.

\section{PENDAHULUAN}

Santae Familiae adalah karya genre opera, yang diambil dari bahasa Latin yang berarti keluarga kudus. (Bantolo, wawancara 03 Juli 2018). Koreografi Santae Familiae menggunakan gerak tradisional gaya Surakarta sebagai acuannya. Penyajian karya Santae Familiae dibagi menjadi beberapa kelompok pendukung yaitu kelompok setan, kelompok malaikat, serta dua tokoh yaitu Maria dan Yusuf sebagai tokoh utama, dalam karya tersebut. Pertunjukan tari Sanctae Familiae didukung oleh musik yang dipimpin oleh Blacius Subono dan Antonius Wahyudi Sutrisno, serta paduan suara Voca Erodita dari Universitas Sebelas Maret sebagai backsong dari pertunjukan tersebut. Rama Agustinus yang khotbah di tengah-tangah pertunjukan sebagai bagian dari pertunjukan karya Sanctae Familiae . 
Struktur sajian karya Santae Familiae dibagi menjadi tiga bagian, bagian pertama yaitu pembukaan dengan visualisasi dua tokoh manusia dan ada setan serta malaikat yang ingin menggoda manusia, serta menjelaskan hukuman yang akan menimpa manusia jika melakukan dosa. Bagian kedua pertemuan Maria dengan Yusuf, Maria yang tiba-tiba mengandung kemudian ingin menyampaikan hal tersebut kepada Yusuf, pada adegan ini Yusuf bingung, resah harus mengambil tindakan apa, selanjutnya di tengah-tengah pertunjukan terdapat khotbah dari Pastur dengan tema dan isi tentang cinta kasih. Bagian ketiga peperangan antara setan dan malaikat, yang menggambarkan bahwa manusia yang bisa menempatkan dirinya terhadap sisi setan atau malaikat dalam hidupnya. Dalam peperangan ini tidak ada yang kalah ataupun menang, semua itu tergantung pada manusia yang di simbolkan dengan cinta kasih, ialah dengan kelahiran Yesus.

Tahun 2014 karya tersebut diciptakan oleh Matheus Wasi Bantolo dalam rangka memperingati perayaan Hari Natal gabungan antara Institut Seni Indonesia Surakarta dengan Universitas Sebelas Maret Surakarta, acara tersebut di selenggarakan pada tanggal 16 Januari 2015 di gedung Teater Besar ISI Surakarta.

Ide penciptaan berawal dari cerita Alkitab perjanjian baru yang membahas tentang Maria yang tiba-tiba mengandung anak dari Roh Kudus hingga lahirnya bayi tersebut yang diberi nama Yesus. Wasi Bantolo memiliki tafsir yang berbeda dari suatu peristiwa kelahiran Yesus untuk menjadikan sebuah karya. Ia mengambil dari sisi malaikat dan setan, dimana setan yang sebenarnya muncul dari dalam diri manusia sendiri, dan manusia berada disisi yang berbenturan atau bersebrangan. Malaikat yang biasanya dilihat dengan wujud baik justru dari hal yang buruk (fisik ataupun rupa) bisa saja itu malaikat atau kebaikan, dari pemikiran itu dapat disikapi dengan seimbang yaitu dengan kasih, dengan cinta itu sendiri, yang digambarkan atau disimbolkan dengan kelahiran Yesus.

Wasi Bantolo mempunyai ciri khas didalam berkarya yaitu tembang yang selalu ada di dalam koreografinya. Tiap hasil karya tarinya selalu menggunakan tembang macapat. Menurutnya tembang macapat memiliki kekuatan yang beragam dan menjadi alternatif dalam menentukan bobot atau kualitas karya (Haryono, 2012:104)

Hal yang menarik dalam pertunjukan tersebut adalah aspek koreografinya. Dimana konsep garap koreografinya berangkat dari tari tradisi gaya Surakarta, yang kemudian diungkapkan ulang menjadi kontemporer. Selain itu garap musiknya juga menyajikan model garap kontemporer, yang disajikan secara orkestra. Atas dasar itulah penulis ingin lebih jauh mengetahui tentang koreografi dan kreativitas Sanctae Familiae karya Matheus Wasi Bantolo. Dari penjelasan tersebut maka judul penulisan ini adalah "Koreografi Sanctae Familiae Karya Matheus Wasi Bantolo".

\section{PEMBAHASAN}

\section{Koreografi Sanctae Familiae}

Gereja-gereja di Indonesia mengadakan visualisasi berbentuk pagelaran untuk mengenang kembali peristiwa kelahiran bayi Yesus dengan memvisualisasikannya dalam bentuk pertunjukan. Pertunjukan tidak hanya dilakukan di Gereja, lingkungan setempat 
atau wilayah yang mengadakan visualisasi perayaan Natal. Tetapi juga diadakan di instansi pemerintah, atau lembaga terkait, seperti Universitas Sebelas Maret dan Institut Seni Indonesia Surakarta. Acara yang diadakan untuk memperingati perayaan Natal gabungan Institut Seni Indonesia Surakarta dengan Universitas Sebelas Maret, dikemas dalam bentuk sebuah pertunjukan mengenai kelahiran Yesus.

Sanctae Familiae diambil dari cerita Alkitab Perjanjian Baru pada Injil Matius 1 ayat 18-25, yang bercerita tentang kelahiran bayi Yesus, yaitu pada waktu Maria, IbuNya bertunangan dengan Yusuf, ternyata ia mengandung anak dari Roh Kudus, sebelum mereka hidup sebagai suami isteri. Yusuf bermaksud akan menceraikan Maria secara diam-diam, tetapi tiba-tiba malaikat Tuhan datang melalui mimpi dan berkata : "Yusuf anak Daud, jangan lah engkau takut mengambil Maria sebagai isterimu, sebab anak yang di dalam kandungannya adalah dari Roh Kudus". Sesudah terbangun dari tidurnya kemudian Yusuf berbuat seperti yang telah diperintahkan yaitu mengambil maria sebagai isterinya (Matius 1 ayat 1825).

Matheus Wasi Bantolo adalah koreografer sekaligus sutradara dalam karya tersebut. Ia memiliki tafsir yang berbeda dari suatu peristiwa kelahiran bayi Yesus, yaitu bukan tentang kelahiranNya melainkan tentang sisi malaikat dan setan atau sisi kebaikan dan kejahatan yang ada di bumi. Manusia, setan dan malaikat sebenarnya sama-sama ciptaan Tuhan, tetapi bagaimana manusia bisa menempatkan serta menciptakan dirinya pada sisi sebagai malaikat yang identik dengan kebaikan, ataupun sisi sebagai setan yang identik dengan keburukan atau kejahatan (Bantolo, wawancara 2 November 2018).

Manusia sebenarnya berada diantara dua sisi yaitu hitam dan putih, atau yang disebut grey (abu-abu). Selanjutnya manusia itu sendiri yang akan menempatkan dirinya pada sisi hitam atau putih. Setan dan malaikat sebenarnya muncul dari dalam diri manusia itu sendiri, bagaimana manusia bisa memilih antara kebaikan dan kejahatan (Bantolo, wawancara 2 November 2018).

Malaikat yang identik dengan penggambaran kebaikan, keindahan, dan kecantikan, tetapi di dalam karya tersebut dilihat dengan cara pandang yang berbeda. Justru hal buruk yang dilihat melalui pancaindera, tentang fisik dan rupa bisa saja itu malaikat yang menggambarkan kebaikan. Sementara setan yang identik dengan keburukan atau kejahatan di dalam karya ini digambarkan dengan kehidupan glamour, keinginan-keinginan duniawi dan semua yang dilihat indah di dunia adalah setan yang sebenarnya.

Dapat dilihat di dalam karya tersebut tata rias atau make up pada setan dan malaikat adalah sesuatu yang berbeda. Wasi Bantolo ingin menyampaikan bahwa halhal yang dilihat dengan mata seperti kecantikan atau keinginan daging adalah keburukan yang dapat menjerumuskan manusia ke dalam dosa. Hal tersebut berbeda dengan kelompok malaikat yang berjumlah empat orang penari, dengan keseluruhan riasan wajah yang putih, seperti Punakawan yang wajahnya dominan putih, tetapi riasan mata, bibir, dan alis berbeda dengan Punakawan. Ia ingin menyampaikan bahwa yang dilihat melalui mata berupa fisik yang buruk belum tentu selamanya akan buruk. Dalam pemikiran tersebut dapat disikapi 
bahwa keburukan atau kebaikan, yang dapat mengontrol adalah diri manusia sendiri yaitu dengan kasih dan cinta yang digambarkan atau disimbolkan melalui kelahiran bayi Yesus (Bantolo, wawancara 2 November 2018).

Judul karya Sanctae Familiae diambil dari bahasa Latin yang berarti keluarga kudus. Inti dari karya tersebut adalah pertarungan antara malaikat yang melambangkan kebaikan dan setan yang melambangkan keburukan. Dalam karya tersebut dibagi menjadi dua kelompok, yaitu kelompok setan dan malaikat, serta terdapat dua tokoh yaitu Maria dan Yusuf sebagai tokoh utama.

Struktur sajian karya Sanctae Familiae dibagi menjadi tiga bagian, bagian pertama yaitu pembukaan dengan visualisasi terdapat dua tokoh manusia dan setan serta malaikat yang ingin menggoda manusia. Sementara untuk memperkuat suasana, dibacakan juga narasi yang menjelaskan tentang hukuman yang akan menimpa manusia jika melakukan dosa.

Bagian kedua pertemuan Maria dengan Yusuf, dimana Maria yang tiba-tiba mengandung dan ingin menyampaikan hal tersebut kepada Yusuf. Pada adegan tersebut Yusuf tidak mengerti harus mengambil tindakan apa karena Maria hamil diluar nikah. Hal tersebut yang menjadi konflik batin Yusuf. Pada bagian kedua ini adanya pastur untuk memberi pencerahan kepada Yusuf dalam bentuk khotbah.

Bagian ketiga peperangan antara setan dan malaikat, yang menggambarkan bahwa manusia dapat menempatkan pada sisi setan atau malaikat didalam hidupnya. Dalam peperangan ini tidak ada yang kalah ataupun menang, atau kedua-duanya kalah, dan yang berkuasa adalah manusia itu sendiri. Maria dan Yusuf sebagai simbol perempuan dan laki- laki untuk melengkapi satu sama lain, serta digambarkan dengan cinta kasih, ialah dengan kelahiran bayi Yesus.

\section{Elemen-Elemen Koreografi}

Koreografi Sanctae Familiae adalah sebuah karya tari yang diciptakan oleh Matheus Wasi Bantolo. Sanctae Familiae merupakan karya yang bergenre opera, yang ditampilkan secara kelompok. Opera, merupakan perpaduan yang indah dari musik, tari dan drama. Karya Sanctae Familiae merupakan sebuah karya yang digarap dari perpaduan antara musik orkestra, dengan paduan suara yang disertai narasi serta tari berpancatan dari sebuah cerita Maria dan Yusuf.

\section{Gerak Tari}

Karya Sanctae Familiae yang menggunakan bentuk gerak tradisional gaya Surakarta sebagai acuannya, dapat dilihat dari bentuk-bentuk gerak yang disajikan. Hal itu terjadi karena latar belakang penciptanya dari kecil hingga dewasa yang berkecimpung di kesenian tradisional. Dalam karya ini Matheus Wasi Bantolo menggunakan bentuk gerak yang sesuai dengan tema dan disusun sehingga menjadi rangkaian gerak yang terlihat indah.

Wasi Bantolo menggunakan bentuk gerak tradisional, yang dikembangkan dan disusun menjadi sebuah karya tari untuk mengungkapkan ide gagasan. Berikut beberapa bentuk gerak tradisional yang digunakan dalam karya Sanctae Familiae:

1. Bentuk tangan kambeng yaitu kedua tangan di tekuk dan dirotasi kedalam. 
2. Bentuk tangan Ngithing yaitu ujung ibu jari dan ujung jari tengah menempel hingga membentuk lingkaran.

3. Bentuk ngrayung yaitu ibu jari ditekuk menempel telapak tangan dan jari-jari yang lainnya merapat tegak.

4. Bentuk kepala tolehan yaitu melihat ke kanan atau ke kiri dengan janggut terlebih dulu.

5. Sikap tubuh mendak yaitu kedua kaki di tekuk, lutut menghadap sudut kanan dan kiri.

6. Bentuk kaki jojor yaitu kaki kanan atau kiri diangkat lurus sejajar dengan pinggul.

Bentuk-bentuk gerak tersebut diolah dan dikembangkan menjadi koreo baru yang biasa disebut tari kontemporer. Tari kontemporer merupakan jenis tari yang mencoba tampil dengan kebaruan, dengan sifat mengkini, progress, eksploratif, dan baru. Kebaruan yang dimaksud bukan baru sama sekali yang lepas dari nuansa-nuansa tradisional namun terdapat perbedaan, ada kebaruan yang tidak lazim dalam cara-cara yang dilakukan tradisi (Maryono, 2015:1718).

\section{Tata rias dan Busana}

Sanctae Familiae menggunakan tata rias sesuai dengan karakter masing-masing kelompok, seperti ide garap yang sudah dipaparkan. Kelompok setan terdiri dari penari laki-laki dan perempuan. Penari lakilaki menggunakan rias bagusan (mempertebal garis wajah), sedangkan penari perempuan menggunakan rias cantik Kelompok malaikat, kelompok tersebut menggunakan tata rias wajah yang lucu (gecul) seperti Punakawan, dengan menggunakan sinwit warna putih yang di ibaratkan itu wajah yang buruk.

Tata rias wajah yang digunakan oleh kelompok malaikat perempuan yaitu rias karakter seperti Punakawan, yang terdiri dari sinwit / pidih yang berwarna putih digunakan di seluruh wajah, warna hitam untuk alis dan tahi lalat, warna merah untuk lingkaran dipipi dan sebagai lipstik. Sedangkan untuk kelompok laki-laki terdiri dari sinwit / pidih yang berwarna putih digunakan di seluruh wajah, warna hitam untuk alis, bawah mata, hidung, penebalan garis bibir, penebalan garis lengkung samping mata dan tahi lalat, warna merah untuk listik dan samping mata.

Tokoh Maria menggunakan busana dengan kain batik bermotif cwiri, sampur warna orange dan dipadukan dengan kain warna emas yang dibentuk dodot alit. Tidak ada maksut tertentu dalam penggunaan kain yang dipakai oleh tokoh Maria dan Yusuf, hanya saja mengambil warna dasar hitam. Kain batik bermotif cwiri dengan warna dasar hitam, supaya mendukung rasa agung, berwibawa serta rasa anteb. Bagian kepala menggunakan rambut palsu panjang yang diurai, dengan penutup kepala jaringjaring dan perhiasan seperti bentuk huruf $S$. Hal tersebut berhubungan dengan wanita dari Negara Timur yang ciri khasnya menggunakan penutup kepala. Tokoh Yusuf menggunakan kostum dengan kain batik yang sama dengan Maria, yaitu motif cwiri yang dipadukan dengan kain warna hitam. Bagian kepala tokoh Yusuf hanya menggunakan ikat kepala, sehingga tercipta kesan gagah (Dewi, Wawancara 14 Agustus 2019). 


\section{Iringan}

Iringan atau musik dalam sebuah pertunjukan tari dapat digunakan sebagai penunjang dan memiliki peranan yang sangat penting pada adegan atau sebagai penguat rasa yang akan di munculkan dalam karya tersebut.

Musik dalam karya Sanctae Familiae memiliki peran sebagai iringan tari, ilustrasi dan sebagai pendukung suasana. Sanctae Familiae menggunakan jenis musik garapan baru, yang disebut musik orkestra gamelan dipadukan dengan alat musik barat dan ditambah dengan garapan musik choir (paduan suara) yang benuansa kristiani, dengan penata musik Blacius Subono dan Antonius Wahyudi Sutrisno. (Wahyudi Sutrisno, wawancara 30 Oktober 2018)

Musik dalam karya Sanctae Familiae masih menggunakan pola-pola karawitan yang telah ada ataupun garapan baru. Polapola tersebut yaitu sirep pada adegan awal, pola kebyar, pola undur-undur, pathetan, srepeg tlutur, palaran dan sampak. (Wahyudi Sutrisno, wawancara 30 Oktober 2018).

\section{Narasi}

1. Pada mulanya Allah kekal adanya

Berhiaskan terang mulia dan Agung tanpa batas

Maha kuasa, Maha tau, Maha hikmat, Maha kasih

Tiada yang paham rencanaNya ataupun memberi nasihat kepadaNya

Karena Dia, kepada Dia, dan memalui Dia segala sesuatu terjadi

2. Atas kesempurnaan dan gambaran keAgunganNya

Allah menciptakan para malaikat manusia dan setan

\begin{abstract}
Allah membentuk mereka dari bara api dan tanah

Kekuatan dan keindahan dia kurniakan pada mereka
\end{abstract}

Sedang tugas yang diberikan pada mereka adalah memuliakan Allah

\section{Jumlah Penari dan Jenis Kelamin}

Jumlah penari dan jenis kelamin merupakan unsur sangat penting didalam koreografi kelompok. Pertimbangan jumlah penari dan jenis kelamin dapat disesuaikan dengan tema yang akan digarap dalam karya tersebut. Namun dalam karya ini, tidak ada batasan khusus untuk jumlah penari dan jenis kelamin.

Pemilihan postur tubuh dalam kelompok penari setan dipilih yang tidak gemuk, karena dilihat dari gerakannya yang menggunakan tenaga yang lebih, dan lincah khususnya untuk penari laki-laki. Postur tubuh yang gemuk dan kurus dipilih untuk kelompok malaikat, yang disimbolkan bahwa hidup itu bervariasi dan supaya dapat membawakan gerakan geculan (lucu). Jumlah penari dalam karya tersebut yaitu enam orang penari perempuan, dan tujuh orang penari laki-laki.

\section{Kreativitas Matheus Wasi Bantolo Dalam Penyusunan Karya Sanctae Familiae Eksplorasi}

Proses ekplorasi yang dilakukan oleh Matheus Wasi Bantolo ialah mengeksplor ide atau pengalaman yang telah didapatkannya. Ia mencoba mengingat dan membuka pikiranya mengenai film serta buku yang telah dilihat dan dibaca. Mengeksplor ide serta memahami persoalan-persoalan dibalik peristiwa kelahiran Yesus didalam konteks 
Natal, hingga bertemu dengan tukang parkir maka ia berimajinasi bahwa malaikat merupakan sosok yang sangat sederhana, sedangkan setan merupakan sosok yang gemilang.

\section{Improvisasi}

Gerak yang digunakan dalam karya Sanctae Familae merupakan gerak-gerak tradisional gaya Surakarta sebagai acuannya. Gerak yang dimaksut yaitu srisig, sabetan, tanjak kaki kanan atau kiri, bentuk tangan ngithing, kambeng, ngrayung. Gerak tersebut diolah dan dikembangkan sehingga mempunyai kebaruan-kebaruan, atau terciptanya gerak-gerak baru yang lebih masa kini dan eksploratif. Misalnya gerak meroda untuk penari setan laki-laki, kayang, dan tolehan kepala yang bervolume besar, gerak golek iwak yang dilakukan dengan level rendah ataupun ngayang. Proses improvisasi gerak Matheus Wasi Bantolo tidak pernah membatasi penari untuk mencari vokabuler-vokabuler gerak baru. Hal tersebut merupakan cara yang dilakukan untuk memperbanyak vokabuler gerak.

Cara Matheus Wasi Bantholo dalam melakukan improvisasi pada tahapan ini yaitu, memberikan ruang kebebasan untuk melakukan respon-respon secara spontan dan mengisi ruang-ruang kosong pada musik. Penari mencoba merespon dengan musik terlebih dulu kemudian dengan peristiwa seperti ini dapat didasarkan pada imajinasi dangerakan. Dimulai dari dua atau tiga penari terlebih dahulu, kemudian poin gerakannya dapat digabung dengan penari lainnya (Bantolo, wawancara 10 Mei 2019).

\section{Tujuan dan Isi Penciptaan Karya}

Karya ini diciptakan untuk memperingati Hari Raya Natal pada tahun 2014, Institut Seni Indonesia Surakarta dengan Universitas Sebelas Maret Surakarta. Perayaan Natal ini diselenggarakan di gedung Teater Besar Institut Seni Indonesia Surakarta. Selain untuk memperingati Hari Raya Natal tujuan diciptakan karya ini adalah untuk menyampaikan pesan bahwa semua manusia sama dimata Tuhan yang artinya tidak ada bedanya. Karena cinta itu tidak mengenal kebaikan atau keburukan, karena Tuhan adalah cinta. (Bantolo, Wawancara 2 November 2018)

Wasi Bantolo mencoba memvisualisasikan drama kelahiran bayi Yesus, dalam sebuah pertunjukan opera yang berjudul Sanctae Familiae yang diambil dalam bahasa Latin. Sanctae Familiae merupakan karya yang bertemakan cinta kasih, ia ingin mengungkapkan bahwa sisi malaikat dan sisi setan berasal dari dalam diri manusia, tinggal bagaimana manusia itu bisa memposisikan sebagai malaikat atau setan didalam pribadinya masing- masing. Karya ini disusun dengan pesan sebagai penguatan dan kesadaran bagi umat yang hadir.

\section{PENUTUP}

Santae Familiae merupakan karya genre opera, yang terinspirasi dari cerita Alkitab Perjanjian Baru pada Injil Matius 1 ayat 18-25, yang bercerita tentang kelahiran bayi Yesus serta buku dan film Jesus of Nazareth, The Passion of the Christ, Angel and Demons yang telah dilihat maupun dari pengalaman-pengalaman dalam karya sebelumnya. Hal tersebut digunakan sebagai ide penciptaan untuk menciptakan karya 
Sanctae Familiae. Bentuk sajian karya tersebut merupakan hasil kesatuan dari elemen-elemen yang saling berhubungan, diantaranya ialah gerak tari, tata rias dan busana, iringan tari, laighting, jumlah penari dan jenis kelamin, tema, ruang tari, judul tari, mode atau cara penyajian, tipe atau jenis tari.

Proses pembentukan karya Santae Familiae merupakan hasil kreativitas dari koreografer. Penggembangan proses kreatif Matheus Wasi Bantolo dapat diklarifikasi dengan menggunakan tahapan ekplorasi. Dalam tahapan ekplorasi terdapat tahap merasakan dan melihat, menghayati, imajinasi atau mengkhayalkan. Tahapan tersebut guna untuk mengeksplorasi ide dan gerak yang telah diperoleh dari pengalaman koreografer sebelumnya. Tahapan improvisasi, dimana penari melakukan respon secara spontan terhadap ruangruang yang kosong terhadap musik, hingga menemukan vokabuler-vokabuler yang tepat dengan suasana atau rasa yang dimunculkan yaitu tenang, damai, sedih dan menegangkan. Tahapan yang terakhir yaitu komposisi atau menyusun, dimana vokabuler yang telah didapatkan disusun sehingga menjadi satu rangkaian gerak, yang dikemas menjadi tiga adegan dan disajikan dengan totalitas. Melalui kreativitas dan kepekaannya terdahap lingkungan, pengalaman hidup dan imajinasinya Matheus Wasi Bantolo berhasil menyajikan koreografi santae familiae dengan totalitas.

\section{DAFTAR PUSTAKA}

Ayu, Putri. "Tinjauan Koreografi Tari Yakso Jati Di Desa Sukabumi Kecamatan Cepogo Kabupaten Boyolali". Skripsi S-1 ISI Surakarta. 2010
Brook, Peter. Percikan Pemikiran Tentang Teater, Film Dan Opera.

Terjemahan Max. Arifin. Yogyakarta. MSPI. 2002

Ginanjar, Dona Dhian. "Pemeran Tokoh Panji Inu Kertapati dalam Karya Tari Topeng Panji Kayungyun karya Wasi Bantolo". Skipsi karya seni S-1 ISI Surakarta. 2011

Hadi, Y Sumandiyo. Buku aspek-aspek koreografi kelompok. Yogjakarta. Lembaga Kajian Pendidikan dan Humaniora Indonesia. 2003

Hawkins, Alma. Mencipta Lewat Tari (Creating Through Dance). Terjemahan Y. Sumandyo Hadi. Yogyakarta. Institut Seni Indonesia Yogyakarta. 1990.

\section{. Bergerak Menurut Kata}

Hati (Moving From Within).

Terjemahan I Wayan Dibia. Jakarta.

Ford Foundation dan Masyarakat Seni Pertunjukan Indonesia. 2003.

Hartanto. Teater Daerah Indonesia. Yogjakarta. Kanisius (Anggota IKAPI). 1996.

Haryono, Sutarno. "Implementasi Konsep Langendriya Mandraswara terhadap Seniman Muda," Jurnal Seni dan Budaya Panggung Vol. 22 No. 1 (Januari-Maret 2012): 94-106

Iswantara, Nur. Kreativitas: Sejarah, Teori $\mathcal{E}$ Perkembangan. Yogjakarta. Gigih Pustaka Mandiri. 2017 
Keene, Michael. Kristianitas. Terjemahan F.A Soeprapto. Yogyakarta. Penerbit Kanisius (Anggota IKAPI). 2006

Kartika, S. Dharsono. Estetika. Bandung. Rekayasa Sains. 2007

La, Meri. Komposisi Tari, Elemen-Elemen Dasar (Dance Composition, The Basic elemen). Terjemahan Soedarsono. Yogyakarta: Institut Seni Indonesia Yogyakarta. 1975.

Maryono. Prakmatig Genre Tari Pasihan Gaya Surakarya. Surakarta. ISI Press. 2010. .Analisa Tari. Surakarta. ISI Press. 2015

Moleong, J Lexy. Metodologi Penulisan Kualitatif. Bandung. Remaja Rosdakarya Offset. 1996.

Munandar, S. C. Utami. Kreativitas dan Keberbakatan: Strategi Mewujudkan Potensi Kreatif dan Bakat. Jakarta. Gramedia Pustaka Utama. 1999.

Murgiyanto, Sal. Koreografi. Jakarta. P.T. Ikrar Mandiri Abadi. 1992.

\section{Ketika Cahaya Merah}

Memudar. Jakarta. Deviri Ganan. 1993.
Nugrahini, Elisa Vindu. "Pemeran Tokoh Sekartaji Karya Tari Topeng Panji Kayungyun". Skipsi karya seni S-1 ISI Surakarta. 2011.

Putri, Praja Dihasta. "Kepenarian Topeng Dalam Karya Tari Kayungyun". Skipsi karya seni S-1 ISI Surakarta. 2017.

Syauri, Ahmad Syofyan. "Koreografi Tubuh Yang Bersembunyi Karya Eko Supendi". Skripsi S-1 ISI Surakarta. 2017.

Tasman, A. Analisis Gerak dan Karakter. Surakarta. ISI Press Surakarta. 2006.

Wahyu, Dwi Widiyastuti. "Koreografi Tari Prajuritan Di Desa Candigaron Kecamatan Sumowo Kabupaten Semarang". Skripsi S-1 STSI Surakarta. 1996

Wulandari, Dewi. "Koreografi Rasa Gundah Geometris Karya Eko Supendi". Skripsi S-1 ISI Surakarta. 2017

Widaryanto, F.X. Koreografi. Bandung. Jurusan Tari STSI Bandung. 2009

Widyastutiningrum, Wahyudiarto. Koreografi 1. Surakarta. ISI Press. 2011.

\section{NARASUMBER}

1. Matheus Wasi Bantolo. (44 tahun), koreografer. Surakarta 


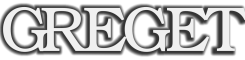

2. Silvester Pamardi. (59 tahun). Penulis naskah. Sukoharjo

3. David Bima Sakti Wardana. (28 tahun), penari tokoh Yusuf. Magelang.

4. Mauritius Tamdaru Kusumo. (24 tahun), penari dalam kelompok malaikat. Pasar kliwon, Surakarta.

5. Reza antarika. (26 tahun), penari tokoh Maria. Surakarta
6. Dewi kristiyanti. ( 59 tahun), penata busana. Surakarta

7. Yosua Wiba. (22 tahun ), paduan suara Voca Erodita. Surakarta

8. Antonius Wahyudi Sutrisno ( 59 tahun), penata musik. Karanganyar.

9. Supriadi (43 tahun), penata lighting. Mojolaban Sukoharjo 